\title{
Integration of Robots into CIM
}




\section{Integration of Robots into CIM}

Edited by

R. Bernhardt

Researcher IPK Berlin, Germany

\section{R. Dillman}

Professor in Computer Science Faculty for Informatics

Institute for Real-Time Computer Control Systems and Robotics, University of Karlsruhe, Germany

\section{K. Hörmann}

Assistant Professor of Computer Science Faculty for Informatics Institute for Real-Time Computer Control Systems and Robotics University of Karlsruhe, Germany

\section{K. Tierney}

Manager of CIM Research Unit University College Galway, Ireland 


\section{First edition 1992}

(c) 1992 Springer Science+Business Media Dordrecht Originally published by Chapman \& Hall in 1992

Softcover reprint of the hardcover 1st edition 1992

Apart from any fair dealing for the purposes of research or private study, or criticism or review, as permitted under the UK Copyright Designs and Patents Act, 1988, this publication may not be reproduced, stored, or transmitted, in any form or by any means, without the prior permission in writing of the publishers, or in the case of reprographic reproduction only in accordance with the terms of the licences issued by the Copyright Licensing Agency in the UK, or in accordance with the terms of licences issued by the appropriate Reproduction Rights Organization outside the UK. Enquiries concerning reproduction outside the terms stated here should be sent to the publishers at the London address printed on this page.

The publisher makes no representation, express or implied, with regard to the accuracy of the information contained in this book and cannot accept any legal responsibility or liability for any errors or omissions that may be made.

A catalogue record for this book is available from the British Library

Library of Congress Cataloging-in-Publication data

Integration of robots into CIM / edited by R. Bernhardt . . . [et al.].

-1 st ed.

p. $\mathrm{cm}$.

Includes bibliographical references and index.

ISBN 978-94-010-5046-3 ISBN 978-94-011-2372-3 (eBook)

DOI 10.1007/978-94-011-2372-3

1. Computer integrated manufacturing systems. 2. Robots, Industrial. I. Bernhardt, Rolf. 1934-

TS155.6.I5535 1992

$670.42^{\prime} 72-\mathrm{dc} 20$ 


\section{Contents}

Contributors vii

Foreword xiv

Section I Survey of the project 1

1 Robots in CIM 3

2 Objectives, approaches and main benefits 6

3 Introduction and role of the partners 19

4 Structure of the book $\quad 24$

$\begin{array}{ll}\text { Section II Systems-planning } & 27\end{array}$

5 Procedure for a computer-aided planning process 29

6 Task sequence planning 36

7 Component selection and layout planning $\quad 45$

8 Process planning $\quad 58$

9 Layout optimization $\quad 65$

$\begin{array}{ll}10 \text { Conclusion to system planning } & 77\end{array}$

\section{Section III Programming}

11 Introduction to programming methods $\quad 83$

12 Robot motion execution planning $\quad 87$

13 Robot program generation $\quad 98$

14 Process execution simulation 101

15 Program execution 115

16 Task-level programming 122

17 Exception handling 168

18 Conclusions 208

Section IV Information system $\quad 211$

$\begin{array}{ll}19 \text { Introduction } & 213\end{array}$

20 Design management system 216

21 Design of a knowledge-based information system 229

22 Conclusions 245

Section V Applications of the system 249

$\begin{array}{ll}23 \text { Introduction } & 245\end{array}$

24 Planning and programming of a dot matrix printer assembly 254

25 Programming of the Cranfield assembly benchmark 263

26 Industrial application of the planning and interactive

$\begin{array}{ll}27 & \text { Applications at FIAR } \\ \end{array}$ 
28 Applications at KUKA and benefits 302

29 Applications at the IPK Berlin 313

30 Conclusions $\quad 326$

Section VI Summary $\quad 329$

31 Major achievements 331

32 Exploitation of results 333

33 Standardization aspects $\quad 337$

34 The future of robots in CIM 341

$\begin{array}{ll}\text { Index } & 345\end{array}$ 


\title{
Contributors
}

\author{
Dr. Rolf Bernhardt
}

IPK

Fraunhofer-Institut für Produktionsaniagenund Konstruktionstechnik

Pascalstraße 8-9

D - 1000 Berlin 10, Germany

Mr Paolo Bison

LADSEB

Consiglio Nazionale delle Ricerche

Istituto per Ricerche di Dinamica del Sistemi

Corso Stati Uniti 4

1 - 35020 Padova, Italy

Prof. Dr. Jim Browne

UCG

University College Galway

Dep. of Industrial Engineering

CIM Research Unit

Nun's Island

Galway

Eire

\section{Mr V. Caglioti}

POLIMI

Politechnico di Milano

Dip. di Elettronica

Piazza L. Da Vinci 32

1 - 20133 Milano

Italy

Dr Luis M. Camarinha-Matos

PSI

Gesellschaft für Prozeßsteuerungsund Informationssyteme $\mathrm{mbH}$

AT-2

Heilbronner Straße 10

D - 1000 Berlin 31

Germany 
Prof. Dr. Rüdiger Dillman

University of Karlsruhe

Institute for Process Computer

Control and Robotics

Postfach 6980

D 7580, Karlsruhe 1, Germany

Mr Bertrand Duffau

Renault Automation

Sa 0981

8 - 10 avenue Emile-Zola

F - 92109 Boulogne Billancourt

Cedex, France

Mr B. Frommherz

UKA

University of Karlsruhe

Institute for Process Computer

Control and Robotics

Postfach 6980

D 7580 Karlsruhe 1,

Germany

Mr R. Gallerini

FIAR

Via Mercantesse 3

1 - 20021 Baranzate

Milano, Italy

Mr Volker Gleue

IPK Fraunhofer-Institut für Produktionsaniagen und Konstruktionstechnik Pascalstraße 8-9

D - 1000 Berlin 10

Germany

Dr Klaus Hörmann

Forschunzenstrum Informatik

Hald-u. -Neu-Str. 10-14

D - 7500 Karlsruhe 1

Germany 
Mr J. Hornberger

UKA

University of Karlsruhe

Institute for Process Computer

Control and Robotics

Postfach 6980

D 7580 Karlsruhe 1, Germany

Mr W. Jakob

PSI

Gesellschaft für Prozeßsteuerungsund Informationssyteme $\mathrm{mbH}$

AT-2

Heilbronner Straße 10

D - 1000 Berlin 31

Germany

Prof. Dr. A. Jimenez

UPM

Universidad Politecnica de Madrid

Departamento de Ingenieria de Sistemas y Automatica

C./J. Gutierrez Abascal 2

E - 28006 Madrid

Spain

Mr Volker Katschinski

IPK

Fraunhofer-Institut für Produktionsaniagen und Konstruktionstechnik Pascalstraße 8-9

D - 1000 Berlin 10

Germany

Mr B. Kottke

PSI

Gesellschaft für Prozeßsteurungsund Informationssysteme mbH

AT-2

Heilbronner Straße 10

D - 1000 Berlin 31

Germany 


\section{Mr Stephan Krüger}

IPK

Fraunhofer-Institut für Produktionsaniagen und Konstruktionstechnik

Pascalstraße 8-9

D-1000 Berlin 10

Germany

Mr Geleyn R. Meijer

UA

University of Amsterdam

FWI

Kruislaan 403

NL - 1098 SJ Amsterdam

Netherlands

Mr C. Mirolo

LADSEB

Consiglio Nazionale delle Ricerche

Istituto per Ricerche di Dinamica del Sistemi

Corso Stati Uniti 4

1-35020 Padova

Italy

Prof. Dr. E. Pagello

LADSEB

Consiglio Nazionale delle Ricerche

Istituto per Ricerche di Dinamica del Sistemi

Corso Stati Uniti 4

1-35020 Padova

Italy

Mr A. Pezzinga

FIAR

Via Mercantesse 3

1 - 20021 Baranzate

Milano

Italy 
Prof. Marco Somaivico

POLIMI

Politecnico di Milano

Dip. di Elettronica

Piazza L. Da Vinci 32

1 - 20133 Milano

Italy

\section{Ms L. Stocchiero}

\section{LADSEB}

Consiglio Nazionale delle Ricerche

Istituto per Ricerche di Dinamica del Sistem

Corso Stati Uniti 4

$1-35020$

Padova

Italy

\section{Ms K. Tierney}

UCG

University College Galway

Dep. of Industrial Engineering

CIM Research Unit

Nun's Island

Galway

Eire

\section{Mr Ugo Negretto}

UKA

University of Karlsruhe

Institute for Process computer

Control and Robotics

Postfach 6980

D 7580

Karlsruhe 1

Germany

\section{Mr S. Wadwha}

UCG

University College Galway

Dep. of Industrial Engineering

CIM Research Unit

Nun's Island Galway

Eire 


\section{Dr Francisco Sastrón}

UPM

Universidad Politecnica de Madrid

Departamento de Ingenieria de Sistemas y Automatica

C./J. Guiterrez Abascal 2

E - 28006 Madrid

Spain

\section{Mr Gerhard Schrek}

IPK

Fraunhofer-Institut für Produktionsaniagen und Konstruktionstechnik Pascalstraße 8-9

D - 1000 Berlin 10

Germany

\section{Mr K. Schröer}

IPK

Fraunhofer-Institut für Produktionsaniagen und Konstruktionstechnik Pascalstraße 8-9

D - 1000 Berlin 10

Germany

\section{Mr Georg Stark}

\section{KUKA}

Schweißaniagen \& Roboter GmbH

Abt. STK-EP

Blücherstraße 144

D - 8900 Augsburg

Germany

Prof. Dr. A. Steiger-Garçáo

UNL

Universidade Nova de Lisboa

FCT - Departamento de Informatica

Quinta da Torre

P-2825 Monte Caparica

Portugal 
Mr Peter Welgele

KUKA

Schweißanlagen \& Roboter $\mathrm{GmbH}$

Abt. STK-EP

Blücherstraße 144

D-8900 Augsburg

Germany

Mr G. Werling

UKA

University of Karlsruhe

Institute for Process Computer

Control and Robotics

Postfach 6980

D 7580 Karlsruhe 1

Germany 


\section{FOREWORD}

From its inception in 1983, ESPRIT (the European Strategic Programme for Research and Development in Information Technology) has aimed at improving the competitiveness of European industry and providing it with the technology needed for the 1990s.

Esprit Project 623, on which most of the work presented in this book is based, was one of the key projects in the ESPRIT area, Computer Integrated Manufacturing (CIM). From its beginnings in 1985, it brought together a team of researchers from industry, research institutes and universities to explore and develop a critical stream of advanced manufacturing technology that would be timely and mature for industrial exploitation in a five year time frame. The synergy of cross border collaboration between technology users and vendors has led to results ranging from new and improved products to training courses given at universities.

The subject of Esprit Project 623 was the integration of robots into manufacturing environments. Robots are a vital element in flexible automation and can contribute substantially to manufacturing efficiency. The project had two main themes, off-line programming and robot system planning. Off-line programming enlarges the application area of robots and opens up new possibilities in domains such as laser cutting, and other hazardous operations. Reported benefits obtained from off-line programming include:

- significant cost reductions because re-programming eliminates robot down-time;

- faster production cycles, in some cases time-savings of up to $85 \%$ are reported;

- the optimal engineering of products with improved quality.

Moreover, off-line programming techniques protect the operator, who under conventional systems of on-line programming, is at a risk of injury from having to work in the physical proximity of the robot.

The integration of robots in manufacturing cells requires the integration of information concerning product design, plant availability and system layout. Project 623 has achieved this through the use of relational and knowledge databases which lead to large cost savings for vendors providing turnkey systems and users who need fast adaptation to production demands.

The project has been an excellent example of a multi-disciplinary approach, combining the knowhow of mechanical and manufacturing engineers and computer scientists to push forward the frontiers of knowledge in an application domain which is at the leading edge of the major European economies. 